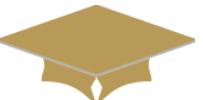

MEDRESEARCH

www.medresearch.in

\title{
Knowledge and practices regarding use of iodised salt among population of selected goitre endemic districts of Bihar
}

\author{
Anwar K. ${ }^{1}$, Kumar D. ${ }^{2 *}$, Sinha N. ${ }^{3}$, Mukherjee M. ${ }^{4}$, Singh R. ${ }^{5}$ \\ DOI: https://doi.org/10.17511/ijphr.2018.i3.01 \\ 4 Madhumita Mukherjee, Assistant Professor, Department of Community Medicine, Patna Medical College, Patna, Bihar, India.
}

${ }^{1}$ Khalid Anwar, Junior Resident, Department of Community Medicine, Patna Medical College, Patna, Bihar, India.

2* Dhananjay Kumar, Tutor, Department of Community Medicine, Patna Medical College, Patna, Bihar, India.

3 Nivedita Sinha, Assistant Professor, Department of Community Medicine, Patna Medical College, Patna, Bihar, India.

5 Rashmi Singh, Professor \& Head, Department of Community Medicine, Patna Medical College, Patna, Bihar, India.

\begin{abstract}
Background: Iodine deficiency disorders (IDDs) are important public health problem which can be prevented by consumption of iodized salt. For sustainable elimination of IDDs, the goal of universal salt iodization (USI) is to cover more than $90 \%$ of household to consume adequately iodized salt. This study was conducted with objectives to assess knowledge and practices regarding salt consumption and to find the factors associated with consumption of adequately iodized salt in selected districts of traditional goitre belt of Bihar. Materials and Methods: The study was a community based cross-sectional study conducted in three districts of Bihar by using cluster sampling technique from January 2018 to March 2018. Results: Only 1.7\% children and 33\% adults were able to identify the condition of goitre. Among adults who identified the case as goitre, around $52 \%$ respondents had correct knowledge about cause of goitre. Around 30\% caregivers knew the brand name of salt that was used in their household and only $19 \%$ of adults had heard about iodized salt.In around 13\% households; salt was added at the end of cooking during food preparation. Adequately iodized salt was consumed in $73.5 \%$ households. The salt stored in air tight container had significantly higher iodine content in comparison to salt stored in open container $(p=0.041)$. Conclusion: The knowledge among people regarding IDDs and iodized salt was very poor which need to be focused in our national programme. The goal of USI regarding iodized salt consumption is yet to be achieved in these districts.
\end{abstract}

Keywords: Goitre, Iodized salt, Knowledge and Practice, Bihar

\section{Corresponding Author}

Dhananjay Kumar, Tutor, Department of Community Medicine, Patna Medical College, Patna, Bihar, India. Email: djkum2k4@gmail.com
How to Cite this Article

Anwar K, Kumar D, Sinha N, Mukherjee M, Singh R. Knowledge and practices regarding use of iodised salt among population of selected goitre endemic districts of Bihar. Public Health Rev Int J Public Health Res. 2018;5(3):105-110.

\section{Available From}

https://publichealth.medresearch.in/index.php/ijphr/ article/view/90
To Browse

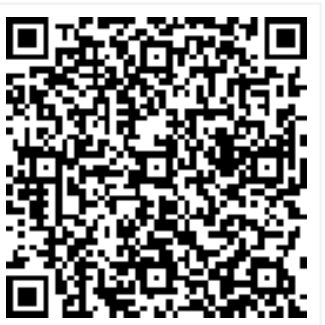

Manuscript Received 2018-07-10

Conflict of Interest No

Review Round 1
2018-07-20
Funding
Nil

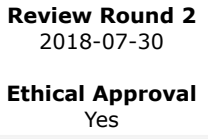

Review Round 3

Plagiarism X-checker $7 \%$
Accepted 2018-08-06

Note

(c) 2018 by Khalid Anwar, Dhananjay Kumar, Nivedita Sinha, Madhumita Mukherjee, Rashmi Singh and Published by Siddharth Health Research and Social Welfare Society. This is an Open Access article licensed under a Creative Commons Attribution 4.0 International License https://creativecommons.org/licenses/by/4.0/ unported [CC BY 4.0]. 


\section{Introduction}

Geographically, Bihar lies in the sub-Himalayan goitre belt. Iodine deficiency causes a spectrum of disorders, from poor growth, retarded development, lowurinary iodine excretion and poor cognitive function and goitre, to severe cognitive disabilityand death.

Consistent consumption of small quantities of iodine can prevent these disorders andreverse some, but not all, of the negative effects of iodine deficiency $[1,2]$.

The World Health Organization (WHO) estimates that approximately $37 \%$ of school-age children (285 million) and nearly 2 billion individuals worldwide, have insufficient iodine intake in $2004[3,4]$.

In 1993, the World Health Organization (WHO), the United Nations Children's Fund (UNICEF) and the International Councilfor the Control of Iodine Deficiency Disorders (ICCIDD) recommended universal iodization of salt to prevent and treat iodine deficiency disorders [5].

Globally, the proportion of people consuming iodized salt rose from less than 20 percent in 1990 to about 70 percent by 2000 but the figure remains stagnant since that date [6].

Though universal salt iodization (USI) was made mandatory in India since 2005 , only $71 \%$ of households were consuming adequately iodized salt (>15ppm) as per the Coverage Evaluation Survey, 2009 [7]. This gap in the utilization of adequately iodized salt couldbe due to various reasons.

Rural residence, illiteracy, lower monthly per-capital income, poor socioeconomic status, unavailability of the salt, lack of awareness about the risk of Iodine Deficiency Disorders (IDD), exposing salt to sunlight, expensiveness, and lack of knowledge about iodized salt are among the factors associated with the absence of adequately iodized salt at home[8].

This study was conducted with following objectives:

01. To assess the proportion of households consuming adequately iodized salt

02. To assess knowledge and practices regarding salt consumption

03. To find the factors associated with consumption of adequately iodized salt in selected districts of traditional goitre belt of Bihar.

\section{Materials and Methods}

The present study was a community based Cross sectional study conducted in Gopalganj, East Champaran and West Champaran districts of Bihar from January 2018 to March 2018. This study was a part of IDD survey assigned to Department of Community Medicine, Patna Medical College, Patna by State Health Society, Bihar. The study population consisted of Children (6-12 years) and caregivers of child (mostly mothers) present at the time of visit.

Sample size calculation: Sample size was calculated using population estimates, where $66 \%$ is the assumed coverage of adequately iodized salt consumption in rural area [9], 95\% confidence level, $10 \%$ margin of error and a design effect of 2 . Thus a sample size of 412 house holds per district and 1236 households for this study was calculated. Cluster sampling was adopted for selection of village as a cluster.

Sampling method: In assigned districts block wise village list was collected for preparing a sampling frame. 3 blocks were randomly selected from each district and from each block 10 villages were selected assuming village as cluster. From each selected village, 14 households were selected randomly and from each household one child of 612 years age group was selected.

If in a house a child of desired age group was not present the neighbouring house was selected for the study. The first choice of caregiver was the mother of child; usually responsible for organizing food preparation in the household.

In absence of mother we interviewed other responsible person who had knowledge about food preparation and salt use in household. All the selected children and their mothers were interviewed to assess their knowledge regarding salt consumption and the salt samples were collected from each household to measure level of Iodine in salt.

Study tools: A pre-tested semi-structured questionnaire was used in every household for collecting information about the knowledge of IDD and practices of iodized salt. The questionnaire was pre-tested in 20 households in another area not selected for the actual study. The necessary modifications and corrections were made on the questionnaire before it was finally administered in the study area. 
Knowledge of Children and their caregivers related to Iodine deficiency disorders were assessed by showing clinical photographs of Goitrous patient and asking that 'do you identify this condition'. If the answer came yes then the name of condition, cause of that condition and source of information regarding the condition were asked. We also assessed their knowledge regarding iodized salt by asking 'have you heard about iodized salt'. If answer came yes then they were asked about 'what are the benefits of consuming iodized salt'. The brand name of the salt used in household was also asked from mothers.

The practices regarding salt consumption were assessed by observing which type of salt they were using that is either refined or granular and the type of container they were using to store the salt after purchasing from the market. Mothers were asked about when they add salt into meal during cooking process i.e. either in the beginning or in between cookingor at the end of cooking.

The socio-economic status was calculated on the basis of Modified BG Prasad classification and then classified into upper, middle and lower class [10].

Salt iodine determination: Salt samples were collected from households that were routinely being consumedin their respective homes in auto-seal polythene pouches. The iodine content was measured by standard iodometric titration method. According to WHO, adequately iodized salt for the sustainable elimination of IDD is defined as salt with iodine content of 15 parts per million (ppm) or more [5].

Method of statistical analysis: Statistical analysis was performed by statistical software SPSS version 22. Frequency distribution and percentages were expressed for categorical variables. The association between salt consumption and various factors were assessed by applying chi-square test. In all cases the level of rejection of a null hypothesis was 0.05 .

Ethical issue: The study was approved by Institute ethical committee of Patna Medical College, Patna. Head of the households were informed about the purpose of the study and written consent was taken from them.

\section{Results}

A total of 1263 children and same number of mothers or any other family members were included in the study. Only 21 children (1.7\%) were able to
Identify the condition of goitre on being shown picture. The main source for their information was book they had studied (66.7\%) followed by television or radio and other sources which include family members, relatives and health workers. Only $1.1 \%$ children had heard about iodized salt. Around $33 \%$ adults were able to identify the condition of goitre on being shown picture. In $29 \%$ adults the source for their information was book they had studied. Television and radio was the source of information in $26 \%$ respondents. Family members, relatives and health workers were source of information in $45 \%$ caregivers. Among those who identified the case as goitre, around $52 \%$ respondents had correct knowledge about cause of goitre. Only $19 \%$ of adults had heard about iodized salt. Only $30 \%$ caregivers know the brand name of salt that was used in their household. (Table: 1 )

\section{Table-1: Knowledge of Children and their caregivers related to Iodine deficiency disorders $(\mathrm{N}=1263)$.}

\begin{tabular}{|c|c|c|c|}
\hline \multicolumn{2}{|l|}{ Variables } & \multirow{2}{*}{\begin{tabular}{|l} 
Frequency \\
21
\end{tabular}} & \multirow{2}{*}{\begin{tabular}{|l} 
Percentage \\
1.7
\end{tabular}} \\
\hline Does child identify the condition & Yes & & \\
\hline \multirow{3}{*}{$\begin{array}{l}\text { If yes, source of information } \\
(n=21)\end{array}$} & Book & 14 & 66.7 \\
\hline & TV & 3 & 14.3 \\
\hline & Other & 4 & 19.0 \\
\hline \multirow[t]{2}{*}{$\begin{array}{l}\text { Reason for Goitre according to } \\
\text { child }(n=21)\end{array}$} & $\begin{array}{l}\text { Iodine } \\
\text { deficiency }\end{array}$ & 14 & 66.7 \\
\hline & Don't know & 7 & 33.3 \\
\hline $\begin{array}{l}\text { Does child has heard about iodized } \\
\text { salt }(n=1263)\end{array}$ & Yes & 13 & 1.1 \\
\hline $\begin{array}{l}\text { Does mother/caregiver identify the } \\
\text { condition }(n=1263)\end{array}$ & Yes & 420 & 33.3 \\
\hline \multirow{3}{*}{$\begin{array}{l}\text { If yes, source of information } \\
(n=420)\end{array}$} & Book & 121 & 28.8 \\
\hline & $\begin{array}{l}\text { Television/R } \\
\text { adio }\end{array}$ & 110 & 26.2 \\
\hline & Others & 189 & 45.0 \\
\hline \multirow[t]{3}{*}{$\begin{array}{l}\text { Reason for Goitre according to } \\
\text { mother/ caregiver }(n=420)\end{array}$} & $\begin{array}{l}\text { Iodine } \\
\text { deficiency }\end{array}$ & 218 & 51.9 \\
\hline & $\begin{array}{l}\text { Drinking of } \\
\text { well water }\end{array}$ & 37 & 22.2 \\
\hline & Don't know & 165 & 8.8 \\
\hline $\begin{array}{l}\text { Does mother/caregiver has heard } \\
\text { about iodized salt }(n=1263)\end{array}$ & Yes & 238 & 18.8 \\
\hline \multirow[t]{2}{*}{ Brand name of salt } & know & 383 & 30.3 \\
\hline & Don't Know & 880 & 69.7 \\
\hline
\end{tabular}

Refined salt was used in every household. The salt was stored in container with closed lid in around $95 \%$ houses, in rest of the houses salt was either stored in container with open lid or open polythene bag. 
In around $87 \%$ houses salt was either added in the beginning or in between cooking. Adequately iodized salt was consumed in $73.5 \%$ household (Table: 2 )

Table- 2: Practices related to Iodised salt consumption in selected districts $(\mathbf{N = 1 2 6 3 )}$.

\begin{tabular}{|l|l|l|l|}
\hline \multicolumn{2}{|c|}{ Variables } & Frequency & Percentage \\
\hline Type of salt & Refined & 1263 & 100 \\
\hline
\end{tabular}

\begin{tabular}{|l|l|l|l|}
\hline \multirow{5}{*}{ Container used to keep the salt } & Container with closed lid & 1199 & 94.9 \\
\cline { 2 - 4 } & Container with open lid & 16 & 1.3 \\
\cline { 2 - 4 } & Polythene bag & 48 & 3.8 \\
\hline Timing of adding salt during cooking & At the beginning & 259 & 20.5 \\
\cline { 2 - 4 } & In between cooking & 835 & 66.1 \\
\cline { 2 - 4 } & At the end of cooking & 169 & 13.4 \\
\hline No. of families consuming adequately Iodized salt & 928 & 73.5 \\
\hline No. of families consuming inadequately Iodized salt & 335 & 26.5 \\
\hline
\end{tabular}

Table 3: Factors associated with iodized salt consumption.

\begin{tabular}{|c|c|c|c|c|c|}
\hline \multicolumn{2}{|c|}{ Variables } & \multicolumn{2}{|c|}{ Iodine level in salt } & \multirow[t]{2}{*}{ Chi-square } & \multirow[t]{2}{*}{ p-value } \\
\hline & & <15ppm & $>15 \mathrm{ppm}$ & & \\
\hline \multirow[t]{2}{*}{ Religion } & Hindu & $278(27.0)$ & $752(73.0)$ & \multirow[t]{2}{*}{0.622} & \multirow[t]{2}{*}{0.43} \\
\hline & Muslim & $57(24.5)$ & $176(75.5)$ & & \\
\hline \multirow[t]{4}{*}{ Category } & OBC & 198(24.8) & $600(75.2)$ & \multirow[t]{4}{*}{10.99} & \multirow[t]{4}{*}{0.012} \\
\hline & sc & $75(30.6)$ & $170(69.4)$ & & \\
\hline & ST & $35(37.6)$ & $58(62.4)$ & & \\
\hline & General & $27(21.3)$ & $100(78.7)$ & & \\
\hline \multirow[t]{3}{*}{ Socio-economic status } & Upper & $31(25.0)$ & $93(75.0)$ & \multirow[t]{3}{*}{1.10} & \multirow[t]{3}{*}{0.58} \\
\hline & Middle & $112(25.1)$ & $334(74.9)$ & & \\
\hline & Lower & $192(27.7)$ & $501(72.3)$ & & \\
\hline \multirow[t]{3}{*}{ House type } & Katchha & $173(31.1)$ & $384(68.9)$ & \multirow[t]{3}{*}{10.675} & \multirow[t]{3}{*}{0.005} \\
\hline & Mixed & $103(23.5)$ & $336(76.5)$ & & \\
\hline & Pucca & $59(22.1)$ & $208(77.9)$ & & \\
\hline \multirow[t]{2}{*}{ Mother's/Caregiver's knowledge about Iodised salt } & No & $73(30.7)$ & $165(69.3)$ & \multirow[t]{2}{*}{2.589} & \multirow[t]{2}{*}{0.108} \\
\hline & Yes & $262(25.6)$ & 763(74.4) & & \\
\hline \multirow[t]{2}{*}{ Knowledge about salt brand } & No & $237(26.9)$ & 643(73.1) & \multirow[t]{2}{*}{0.247} & \multirow[t]{2}{*}{0.619} \\
\hline & Yes & $98(25.6)$ & $285(74.4)$ & & \\
\hline \multirow[t]{2}{*}{ Container used to store salt in household } & In closed vessel & $311(25.9)$ & $888(74.1)$ & \multirow[t]{2}{*}{4.167} & \multirow[t]{2}{*}{0.041} \\
\hline & In open vessel/ Polythene bag & $24(37.5)$ & $40(62.5)$ & & \\
\hline
\end{tabular}

(Figures in parenthesis denotes percentage. OBC: Other Backward Castes, SC: Scheduled caste, ST: Scheduled tribe)

The proportion of people consuming adequately iodized salt was most among General category $(78.7 \%)$ followed by Other Backward Class (75.2\%), Scheduled Caste (69.4\%) and Scheduled Tribe category $(62.4 \%)$ and the association was statistically significant $(p=0.012)$. The family living in Katchha houses had poor iodized salt consumption in comparison to people living in mixed and pucca houses $(p=0.005)$. The salt stored in air tight container had significantly higher iodine content in comparison to salt stored in open container $(p=0.041)$. Religion, socio-economic status, caregiver's knowledge about iodized salt and caregiver's knowledge about brand name of salt had no any significant association with iodized salt consumption (Table: 3 ).

\section{Discussion}

The present study collected information on the iodine content of household salt, knowledge and practices regarding storage of edible salt as well as the factors influencing iodized salt use. One of the objectives of present study was to assess the knowledge of children and adults regarding iodine deficiency disorders.

The knowledge of children was quite poor. As a little age group of 6-12 years we cannot expect too much from them to know about IDD. But one of the aims of National Iodine Deficiency Disorders Control Programme (NIDDCP) is to increase awareness among common people regarding IDDs and iodized salt consumption.

Only $33 \%$ adult were able to identify the condition of goitre. And only $19 \%$ had heard about iodized salt. 
So the knowledge of adults was quite poor regarding these aspects. This poor knowledge is also reflected in their practices.

As we have found the consumption of adequately iodized salt was $73.5 \%$ against the goal of universal salt iodization (USI), which is to cover more than $90 \%$ of households [5]. The target of universal salt iodization is yet to be achieved at the consumer level in the surveyed districts of Bihar.

The use of non-iodized salt was not found in any household. This finding revealed that although the salt was being iodised; either the iodine was added in inadequate quantity or there were losses of iodine at the different points in distribution system.

In present study for $29 \%$ caregivers, the source for their information was book they had studied. Television and radio was the source of information in $26 \%$ respondent. Family members, relatives and health workers were source of information in $45 \%$ caregivers. Roy et al (2016) reported common sources of information for iodized salt were television and radio (60\%) [11].

However, in a study by Sen et al. [12] television $(66.7 \%)$ was the principal sourceof information. The salt was stored in container with closed lid in around $95 \%$ houses in our study. Almost similar finding was reported in a study where salt was stored in container with closed lid in $87 \%$ households [11].

In this study; Category, house status and container used to store salt in household were the factors significantly associated with iodized salt consumption in households. NFHS-4 (2015-16) data of Bihar reported that the iodized salt consumption was highest in households of other category followed by other backward class (OBC), scheduled caste (SC) and scheduled tribe (ST) [13].

Similar trend was found in present study which shows that the proportion of people consuming adequately iodized salt was most among General category (78.7\%) followed by Other Backward Class (75.2\%), Scheduled Caste (69.4\%) and Scheduled Tribe category $(62.4 \%)$.

The adequately iodized salt consumption in these districts was $73.5 \%$ which is around 16 point below the goal of universal salt iodization (USI) [5]. This gap may beeither due to iodine was added in inadequate quantity or there were losses of iodine due to faulty storage practice.
In some instances the quality of iodized salt remains poor, or the salt is incorrectly packaged, or the salt deteriorates due to excessive long term exposure to moisture, heat, and contaminants [5]. We found that salt stored in air tight container had significantly higher iodine content in comparison to salt stored in open container $(p=0.041)$. Kapil $U$ (1998) revealed that the maximum loss of iodine occurred when iodised salt was exposed to sunlight $(40 \%)$ [14].

Halogen nature ofiodine and its exposure to excess oxygen and carbon dioxideslowly oxidizes it to metal carbonate and elemental iodinewhich then evaporates. Exposure to heat also reduces the iodine content of salt [15]. In a study, not exposing salt to sunlight and higher monthly income of respondents showed a strong relationship with the presence of adequately iodized salt at home.

The possible explanation for this might be due to loss of iodine because of exposure to heat, sunlight, and moisture during storage at home or elsewhere in the supply chain $[14,15]$. In the present study, salt was added at the end of cooking during food preparation in around $13 \%$ households. However, to maintain iodine in prepared food the salt should be added to a meal at the end of cooking $[5,6]$.

\section{Conclusion}

Despite NIDDCP being in place formore than 20 years, the consumption of adequately iodized saltin these districts is still below the goal of the program. The knowledge among children and adults regarding IDDs and iodized salt was very poor.

Children are known to be agents of change; therefore, there is need to intensify health education activities in the school curricula so as to increase early awareness among children on the benefits and effects of iodine. The knowledge and practices among adults can be improved byactive participation of our grass root level workers in generatingawareness about the health benefits of consuming adequatelyiodized salt.

\section{Reference}

01. Aburto N, Abudou M, Candeias V, Wu T. Effect and safety of salt iodization to prevent iodine deficiency disorders- a systematic review with meta-analyses. WHO e Library of Evidence for Nutrition Actions (eLENA), Geneva- World Health Organization. 2014.

[Crossref] 
02. Global health risks- mortality and burden of disease attributable to selected major risks. Geneva- World Health Organization. 2009. Available at: [Article] [Crossref]

03. Iodine status worldwide. WHO global database on iodine deficiency. Geneva- World Health Organization. 2004.

Available at: [Article] [Crossref]

04. de Benoist B, McLean E, Andersson M, Rogers L. Iodine deficiency in 2007-global progress since 2003. Food Nutr Bull. 2008;29(3)195-202. [Crossref]

05. WHO/ICCIDD/UNICEF. Assessment of Iodine Deficiency Disorders and monitoring their elimination- A guide for programme managers. Geneva- World Health Organization. 2007; p-735. Available from: [Article] [Crossref]

06. UNICEF. Sustainable Elimination of Iodine Deficiency- Progress Since the 1990. World Summit for Children. 2008.

[Crossref]

07. International council for control of iodine deficiency disorders. IDD newsletter. May 2011, India Vol-39(2).

[Crossref]

08. Kumma WP, Haji Y, Abdurahmen J, Adinew YM. Factors Affecting the Presence of Adequately Iodized Salt at Home in Wolaita, Southern Ethiopia- Community Based Study. International Journal of Food Science. Volume 2018;P-1-9. [Crossref]
09. Pandav CS, Yadav K, Srivastava R, Pandav R, Karmarkar MG. Iodine deficiency disorders (IDD) control in India. Indian journal of medical research. 2013;Sep;138(3)418-433.

[Crossref]

10. Singh T, Sharma S, Nagesh S. Socio-economic status scales updated for 2017. International Journal of Research in Medical Sciences. 2017;5;3264-7.

[Crossref]

11. Roy R, Chaturvedi M, Agrawal D, Ali H. Household use of iodized salt in rural area. Journal of Family Medicine and Primary Care. $2016 ; 5 ; 77-81$.

[Crossref]

12. Sen TK, Das DK, Biswas AB, Chakrabarty I, Mukhopadhyay S, Roy R. Limited access to iodized salt among the poor and disadvantaged in North 24 Parganas district of West Bengal, India. J Health Popul Nutr. 2010;28;369-74.

[Crossref]

13. National Family Health Survey 4 (NFHS 4) 201516.

Available at: [Article] [Crossref]

14. Kapil U, PrakashS, Nayar D. Study of some factors influencing losses of iodine from iodised salt. Indian Journalof Maternal and Child Health. 1998;9(1)pp-46-47.

[Crossref]

15. Waszkowiak K, Szymandera K. Effect of storage conditions on potassium iodide stability in iodised table salt and collagen preparations. International Journal of Food Science \& Technology. 2008;43(5)895-899.

[Crossref] 